\title{
Venous thromboembolism associated with combined oral contraceptive use: a single-institution experience
}

\author{
Yong-Su Jang, MD', Eun Sil Lee, MD², Yang-Ki Kim, MD, PhD \\ 'Department of Obstetrics and Gynecology, Soonchunhyang University Cheonan Hospital, Soonchunhyang University College of Medicine, Cheonan; \\ Departments of ${ }^{2}$ Obstetrics and Gynecology, ${ }^{3}$ Internal Medicine, Soonchunhyang University Seoul Hospital, Soonchunhyang University College of \\ Medicine, Seoul, Korea
}

\section{Objective}

Combined oral contraceptives (COCs) are used for various reasons. However, venous thromboembolism (VTE), a significant side effect, can be fatal. This study reports the first case series in Korea involving patients with COCassociated VTE registered at a university hospital.

\section{Methods}

This study recruited 13 patients diagnosed with COC-associated VTE between June 2006 and May 2018. Risk factors, including age, body mass index, smoking habits, estrogen dosage, type of progestin, and duration of COC use, were evaluated.

\section{Results}

Among patients with VTE, 9 showed pulmonary embolism (PE) concomitant with deep vein thrombosis (DVT). However, the remaining patients showed DVT (1 patient), PE (1 patient), and cerebral venous thrombosis (2 patients). The median duration between the onset of symptoms and a hospital visit was 3 days, and it sometimes took as long as 32 days. Among the 10 patients with PE, 1 high-risk group and 2 intermediate-high risk groups were treated with tissue plasminogen activators before anticoagulants. There were no cases of recurrence among patients who continued to take anticoagulants for 3 months.

\section{Conclusion}

These findings emphasize that healthcare professionals who prescribe or dispense COCs to women must inform them of the risk of VTE, including the risk factors, differences in risk depending on the type of progestin present in the product, and pertinent signs and symptoms. Efforts should also be made to inform patients of VTE, even through information campaigns such as brochures. Most importantly, women should remain alert for signs and symptoms of VTE when using COCs.

Keywords: Contraceptives, oral, combined; Venous thromboembolism; Venous thrombosis; Pulmonary embolism; Intracranial thrombosis

\section{Introduction}

Since their introduction in the 1960s, combined oral contraceptives (COCs) have been used worldwide as safe, effective, and reversible protection against pregnancy. COCs are used by $8 \%$ of women of reproductive age worldwide and constitute the most common contraception method in industrialized countries. It has been reported that among women of reproductive age, the percentages of those who take contraceptives are as follows: $17.8 \%$ in Europe and North America, 21.9\% in Australia and New Zealand, 5.2\% in East
Received: 2020.12.05. Revised: 2021.02.15. Accepted: 2021.03.23. Corresponding author: Yang-Ki Kim, MD, PhD

Department of Internal Medicine, Soonchunhyang University Seoul Hospital, 59 Daesagwan-ro, Yongsan-gu, Seoul 04401, Korea E-mail: kyklung@schmc.ac.kr

https://orcid.org/0000-0003-4221-6689

Eun Sil Lee has been an Editorial Board of Obstetrics \& Gynecology Science; however, she was not involved in the peer reviewer selection, evaluation, or decision process of this article. Otherwise, no other potential conflicts of interest relevant to this article was reported.

Articles published in Obstet Gynecol Sci are open-access, distributed under the terms of the Creative Commons Attribution Non-Commercial License (http://creativecommons. org/licenses/by-nc/3.0/) which permits unrestricted non-commercial use, distribution, and reproduction in any medium, provided the original work is properly cited.

Copyright $\odot 2021$ Korean Society of Obstetrics and Gynecology 


\title{
Obstetrics \& Gynecology Science
}

\author{
Vol. 64, No. 4, 2021
}

and Southeast Asia, and 3.3\% in South Korea [1]. In addition to their contraceptive action, noncontraceptive use of COCs includes treating disorders such as abnormal uterine bleeding, dysmenorrhea, and polycystic ovarian syndrome $[2,3]$. However, concerns over cardiovascular side effects have led to modified COC compositions to reduce the risk of venous thromboembolism (VTE) and other adverse cardiovascular events [4].

VTE is an unavoidable adverse event associated with COCs, and the risk is higher in COC users (3-9 per 10,000 people/ yr) than in non-users (1-5 per 10,000 people/yr) [5]. The risk appears to be higher in preparations containing high doses of estrogen or newer progestins, including desogestrel, gestodene, and drospirenone [6-8]. Said risk can be explained by increased levels of prothrombin and factor VII, and decreased levels of factor $V$ being more pronounced when using 3rd- or 4th-generation COCs [9]. COC-associated VTE is a very rare condition in Korean women, which has caused it to be overlooked by numerous physicians and healthcare professionals. A few case reports have described COC-induced VTE or arterial thrombosis in Korean women [10-14]. However, these describe a single case across different hospitals (Table 1), not as a single or multicenter case series. This study reports the first case series involving 13 patients with COC-associated VTE registered at a thrombosis center at a university hospital.

\section{Materials and methods}

The records of 13 patients with $\mathrm{COC}$-associated venous thromboembolic events registered at a thrombosis center at a Soonchunhyang University Hospital between June 2006 and May 2018 were reviewed. Laboratory tests were performed for thrombophilia, including fibrinogen and D-dimer, and for the estimation of proteins $\mathrm{C}$ and $\mathrm{S}$ and antiphospholipid antibodies.

VTE was diagnosed based on the patient's clinical presentation and confirmed using vascular imaging, including computed tomography or magnetic resonance imaging. DVT was diagnosed when there was no compressibility of the veins of the lower extremities or direct visualization of a clot. PE was diagnosed when there was a filling defect in the pulmonary

Table 1. Summary of reported cases regarding COC-associated VTE in Korea

\begin{tabular}{|c|c|c|c|c|c|c|c|c|c|}
\hline \multirow[b]{2}{*}{ Author (yr) } & \multirow[b]{2}{*}{$\begin{array}{l}\text { Age } \\
(y r)\end{array}$} & \multirow{2}{*}{$\begin{array}{c}\text { Anatomical } \\
\text { location of } \\
\text { VTE }\end{array}$} & \multirow[b]{2}{*}{ Thrombophilia } & \multirow{2}{*}{$\begin{array}{c}\text { Constituent } \\
\text { of COC }\end{array}$} & \multirow{2}{*}{$\begin{array}{l}\text { Duration } \\
\text { of COC }\end{array}$} & \multicolumn{2}{|c|}{ Treatment } & \multirow{2}{*}{$\begin{array}{l}\text { Duration } \\
\text { of } A C\end{array}$} & \multirow{2}{*}{$\begin{array}{l}\text { Recur- } \\
\text { rence }\end{array}$} \\
\hline & & & & & & $\begin{array}{l}\text { Thrombo- } \\
\text { lytics }\end{array}$ & $\begin{array}{l}\text { Anticoagu- } \\
\text { lation }\end{array}$ & & \\
\hline $\begin{array}{l}\text { Park et al. [16] } \\
\text { (2001) }\end{array}$ & 34 & $\begin{array}{l}\text { Cerebral vein, } \\
\text { cerebral sinus }\end{array}$ & None & Unknown & $11 \mathrm{mo}$ & $\begin{array}{l}\text { Systemic } \\
\text { urokinase }\end{array}$ & $\begin{array}{l}\text { UFH and } \\
\text { warfarin }\end{array}$ & Unknown & Unknown \\
\hline $\begin{array}{l}\text { Yeo et al. [15] } \\
\text { (2006) }\end{array}$ & 42 & $\begin{array}{l}\text { SMV, portal } \\
\text { vein }\end{array}$ & $\begin{array}{c}\text { AT III, protein C \& } \\
\mathrm{S} \downarrow\end{array}$ & Unknown & $7 \mathrm{yr}$ & $\begin{array}{l}\text { Intraoperative } \\
\text { urokinase }^{\text {a) }}\end{array}$ & $\begin{array}{l}\text { UFH and } \\
\text { warfarin }\end{array}$ & $1 \mathrm{yr}$ & None \\
\hline $\begin{array}{l}\text { Kang et al. [14] } \\
\text { (2008) }\end{array}$ & 28 & $\begin{array}{c}\text { Pulmonary } \\
\text { artery, renal } \\
\text { vein }\end{array}$ & None & $\begin{array}{c}\text { EE } 0.02 \mathrm{mg} \text {, } \\
\text { desogestrel } \\
0.15 \mathrm{mg}\end{array}$ & $3 \mathrm{mo}$ & Systemic tPA & $\begin{array}{l}\text { UFH and } \\
\text { warfarin }\end{array}$ & $3 \mathrm{mo}$ & None \\
\hline $\begin{array}{l}\text { Kim et al. [12] } \\
\text { (2013) }\end{array}$ & 24 & $\begin{array}{c}\text { Pulmonary } \\
\text { artery, IVC, } \\
\text { external iliac } \\
\text { vein }\end{array}$ & None & $\begin{array}{c}\text { EE } 0.03 \text { mg, } \\
\text { drospirenone } \\
3 \mathrm{mg}\end{array}$ & $4 \mathrm{mo}$ & None & $\begin{array}{l}\text { LMWH and } \\
\text { warfarin }\end{array}$ & $6 \mathrm{mo}$ & None \\
\hline $\begin{array}{l}\text { Park et al. [13] } \\
\text { (2017) }\end{array}$ & 23 & $\begin{array}{l}\text { Pulmonary } \\
\text { artery }\end{array}$ & None & $\begin{array}{c}\text { EE } 0.02 \mathrm{mg}, \\
\text { desogestrel } \\
0.15 \mathrm{mg}\end{array}$ & $6 \mathrm{mo}$ & None & $\begin{array}{l}\text { Rivaroxaban } \\
\text { after LMWH }\end{array}$ & $6 \mathrm{mo}$ & None \\
\hline $\begin{array}{l}\text { Bae et al. [11] } \\
\text { (2018) }\end{array}$ & 27 & $\begin{array}{l}\text { Pulmonary } \\
\text { artery, portal } \\
\text { vein, SMV }\end{array}$ & $\begin{array}{l}\mathrm{LA}(+) \text {, protein } \mathrm{S} \\
\text { activity } \downarrow\end{array}$ & Unknown & $2 \mathrm{yr}$ & $\begin{array}{l}\text { Catheter- } \\
\text { directed } \\
\text { urokinase }^{\mathrm{b})}\end{array}$ & $\begin{array}{l}\text { UFH and war- } \\
\text { farin }\end{array}$ & Unknown & None \\
\hline
\end{tabular}

COC, combined oral contraceptives; VTE, venous thromboembolism; AC, anticoagulation; UFH, unfractionated heparin; SMV, superior mesenteric vein; AT III, antithrombin III; EE, ethinyl estradiol; tPA, tissue plasminogen activator; IVC, inferior vena cava; LMWH, low molecular weight heparin; LA, lupus anticoagulant.

${ }^{\text {a) } A d d ~ s e g m e n t a l ~ s m a l l ~ b o w e l ~ r e s e c t i o n ; ~}{ }^{\text {b) }}$ Add jejunal resection with percutaneous thrombus aspiration and thrombectomy. 


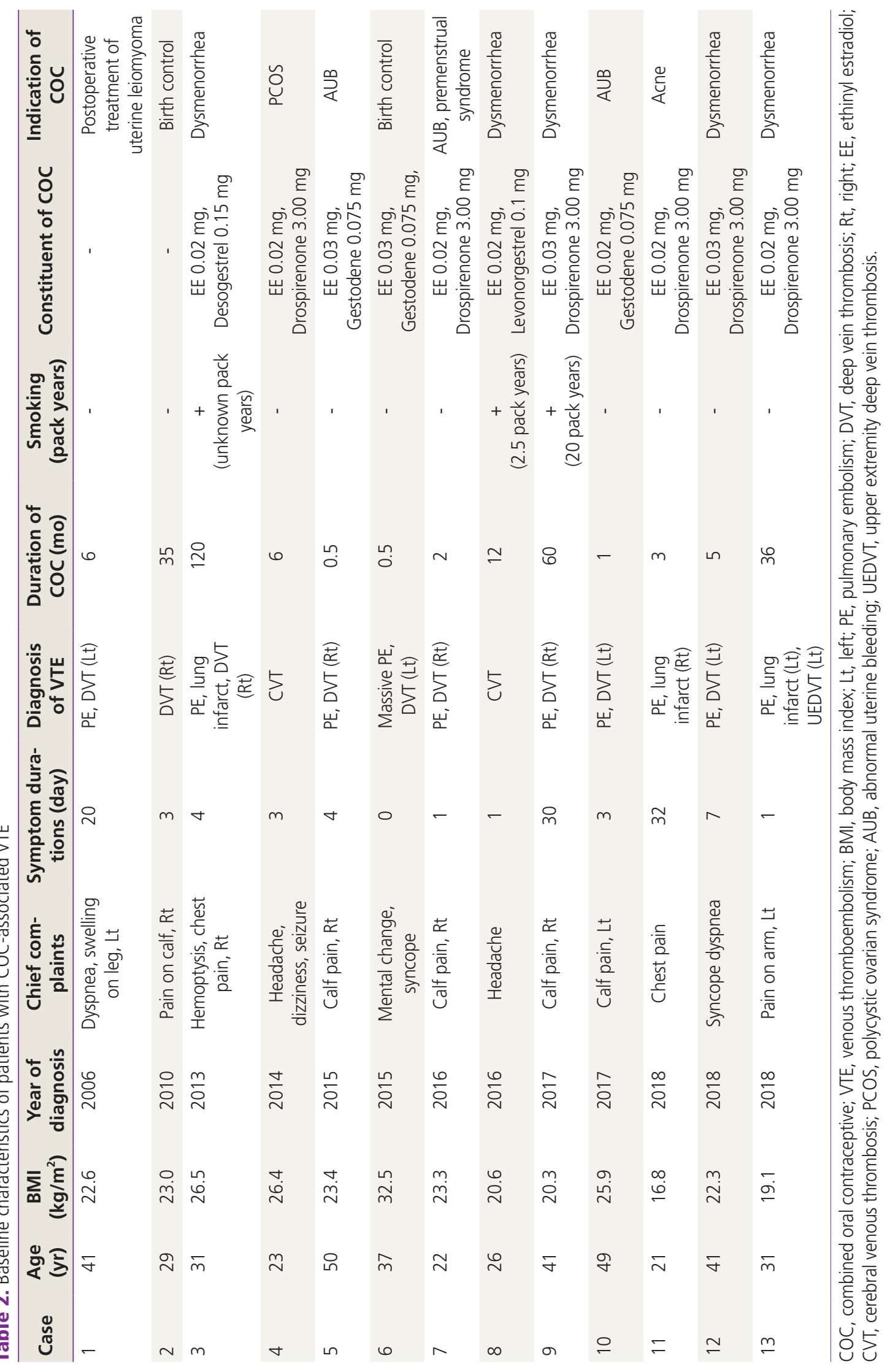




\section{Obstetrics \& Gynecology Science}

Vol. 64, No. 4, 2021

artery or its branches. Cerebral venous thrombosis was diagnosed when the blood clot was present in the dural venous sinuses, cortical vein, or deep cerebral vein.

Risk factors related to COC-associated VTE, including age, body mass index (BMI), smoking habits, estrogen dosage, type of progestin, and duration of COC use, were evaluated. Additionally, COC use, clinical diagnosis, treatment, and hospital discharge outcomes were also recorded. The study protocol was reviewed and approved by Soonchunhyang University Hospital's Institutional Review Board and ethics committee (IRB No. 2018-04-011-001).

\section{Results}

A total of 13 patients were recruited between 2006 and 2018, 9 of whom were hospitalized for COC-related VTE. The mean length of hospitalization was 5.9 days (1-14 days).

\section{Baseline characteristics}

The patients' mean age was $33.4 \pm 10.1$ years. For the patients' age distribution, 5 were 20-29 years old, 3 were 30-39 years old, 4 were 40-49 years old, and 1 was over 50 years old (Table 2). The mean BMl was $23.3 \pm 4.0 \mathrm{~kg} / \mathrm{m}^{2}$. Three patients were overweight (BMl $23.0-24.9 \mathrm{~kg} / \mathrm{m}^{2}$ ), and
4 were obese (BMI $\left.\geq 25.0 \mathrm{~kg} / \mathrm{m}^{2}\right)$. Three patients were smokers at the time of the VTE event, and 10 patients denied a history of smoking. The median duration between the onset of symptoms and the hospital visit was 3 days (range, 0-32 days).

\section{Indications and duration of the $\mathrm{COC}$ administration}

Dysmenorrhea was the most common indication for COC administration (5 cases), followed by abnormal uterine bleed-

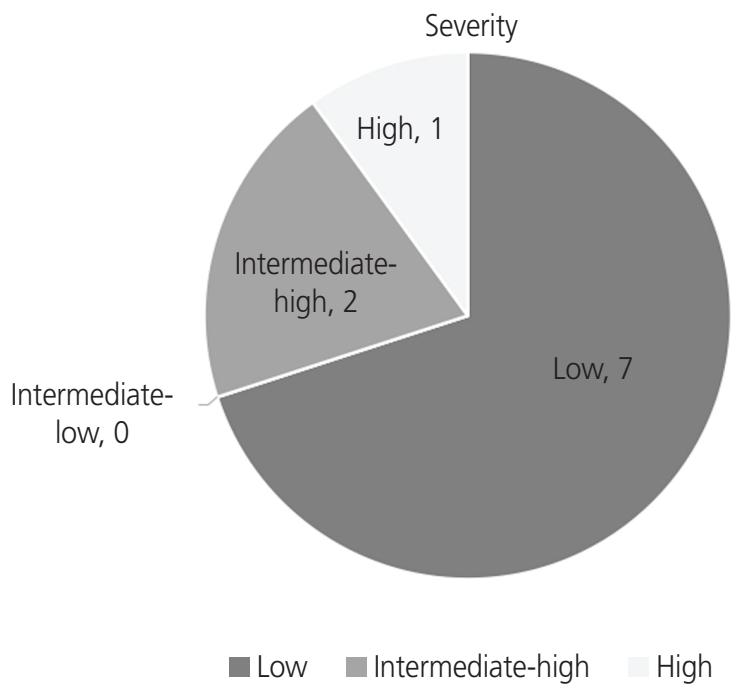

Fig. 1. Class of pulmonary embolism (PE) severity according to the simplified PE severity index.

Table 3. Clinical features and outcomes in patients with COC-associated VTE

\begin{tabular}{|c|c|c|c|c|c|c|c|c|c|}
\hline Case & $\begin{array}{l}\text { Age } \\
(y r)\end{array}$ & $\begin{array}{c}\text { Class of PE } \\
\text { severity }\end{array}$ & $\begin{array}{l}\text { Duration of } \\
\text { admission } \\
\text { (day) }\end{array}$ & $\begin{array}{c}\text { Thrombolytic } \\
\text { therapy }\end{array}$ & $\begin{array}{l}\text { Anticoagu- } \\
\text { lants }\end{array}$ & $\begin{array}{c}\text { Duration of } \\
\text { anticoagula- } \\
\text { tion (day) }\end{array}$ & $\begin{array}{l}\text { APL Anti- } \\
\text { body }\end{array}$ & $\begin{array}{l}\text { Recur- } \\
\text { rence }\end{array}$ & $\begin{array}{c}\text { Major } \\
\text { bleeding/ } \\
\text { CRNMB }\end{array}$ \\
\hline 1 & 23 & Not applicable & 5 & None & Warfarin & Indefinite & None & None & None/None \\
\hline 2 & 26 & Not applicable & 14 & None & Warfarin & 195 & None & None & None/None \\
\hline 3 & 29 & Not applicable & 0 & None & Warfarin & 93 & Unfinished & None & None/None \\
\hline 4 & 21 & Low & 0 & None & Rivaroxaban & Indefinite & $\mathrm{aCL}$ & None & None/None \\
\hline 5 & 22 & Low & 6 & None & Rivaroxaban & 181 & None & None & None/None \\
\hline 6 & 31 & Low & 0 & None & Rivaroxaban & 201 & None & None & None/None \\
\hline 7 & 31 & Low & 12 & None & Warfarin & 466 & None & None & None/None \\
\hline 8 & 41 & Low & 0 & None & Rivaroxaban & 181 & None & None & None/None \\
\hline 9 & 49 & Low & 1 & None & Rivaroxaban & 184 & None & None & None/None \\
\hline 10 & 50 & Low & 2 & None & Rivaroxaban & 152 & None & None & None/None \\
\hline 11 & 41 & Intermediate-high & 4 & tPA & Edoxaban & 182 & None & None & None/None \\
\hline 12 & 41 & Intermediate-high & 6 & tPA & Warfarin & 172 & None & None & None/None \\
\hline 13 & 37 & High & 3 & tPA & Rivaroxaban & Indefinite & None & None & None/None \\
\hline
\end{tabular}

COC, combined oral contraceptive; VTE, venous thromboembolism; PE, pulmonary embolism; APL, antiphospholipid; CRNMB, clinically relevant non-major bleeding; aCL, anti-cardiolipin antibody; tPA, tissue plasminogen activator. 


\title{
Obstetrics \& Gynecology Science
}

\author{
Yong-Su Jang, et al. COC-associated VTE
}

ing (3 cases), contraception (2 cases), polycystic ovarian syndrome (1 case), acne (1 case), and postoperative treatment of leiomyoma ( 1 case). The median COC administration duration was 6 months ( 0.5120 months) (Table 2 ).

\section{Constituents of COCs}

In 2 patients, the constituents of the COCs were not recorded, and the estrogen dosage and the type of progestin could not be confirmed. Of the 11 remaining patients, 7 identified the COC they took, which contained $20 \mu \mathrm{g}$ of ethinyl estradiol (EE), while the remaining 4 took COCs containing $30 \mu \mathrm{g}$ of EE. For the COC progestin component, 1 patient took a 2nd-generation COC containing levonorgestrel, 1 took a 3rd-generation COC containing desogestrel, 3 took a 3rd-generation COC containing gestodene, and 6 took a 4th-generation COC containing drospirenone. Table 2 shows how long each patient used the COCs before their VTE diagnoses.

\section{Anatomical site of VTE}

The most common thromboembolic event associated with COC use is pulmonary embolism (PE) concomitant with deep vein thrombosis (DVT). Nine patients displayed PE concomitant with DVT, 1 had isolated DVT, 1 had isolated PE, and 2 had cerebral venous thrombosis (CVT; Table 2). Of the 10 DVT cases, 9 affected the deep veins in the lower extremities and 1 affected the deep veins in the upper extremity.

\section{Class of PE severity and therapeutic strategies}

Ten patients with PE were classified as low-, intermediate-, or high-risk according to the simplified PE severity index (sPESI). One patient was classified as having a high-risk of hypotension. Two patients were classified as intermediatehigh-risk with right ventricular hypokinesia and positive cardiac biomarkers, and the remaining patients were classified as low-risk. High-risk and intermediate-high-risk patients immediately received a tissue plasminogen activator (tPA) followed by anticoagulants, while low-risk patients received only anticoagulants (Fig. 1). Table 3 outlines the patients' severity classifications and the anticoagulants they received (i.e., edoxaban, rivaroxaban, or warfarin).

\section{Duration of anticoagulation and outcome of treatment}

Anticoagulation was continued for more than 3 months in all patients. In this study, 3 patients consistently took anticoagulants. Two of the 3 patients received indefinite treatment for combined antiphospholipid Ab syndrome, and the remaining patient who experienced shock during a VTE event received medication indefinitely due to fear of re-experiencing shocks.

\section{Recurrence of bleeding after treatment}

None of the patients experienced a recurrence of VTE or a major or clinically relevant non-major bleeding event following the thrombolytic therapy or anticoagulation therapy.

\section{Discussion}

Using hormonal contraceptives contributes to a significant percentage of VTE occurring among women of childbearing age, and VTE is the most important determinant of the riskbenefit profile associated with hormonal contraceptives [4]. The risk of VTE is dependent on age, BMI, the presence of inherited or acquired thrombophilia, duration of COC use, type of pill, and exposure to additional risk factors [15]. Based on a Danish cohort study, incidences of VTE increase with age from 1.84 per 10,000 woman-years in women aged 15-19 to 6.59 per 10,000 woman-years in women aged 45-49 [1618]. Meanwhile, the VTE risk in women using COCs is attributed to changes in hemostasis [19]. Estrogen increases gene expression and the plasma levels of coagulation factors and decreases anticoagulation factor levels, including proteins $C$ and $S$ and tissue factor pathway inhibitors [20-22]. In contrast, progestin upregulates the gene expression of protein $\mathrm{S}$ $[23,24]$.

COCs are classified as prescription drugs in most developed countries, and case reports describing their adverse effects are regularly investigated and recorded. However, most COCs are approved over-the-counter drugs for easy accessibility in South Korea; hence, there is a lack of ways to report this issue. An analysis of adult Korean women taking COCs showed that they were not familiar with the exact use of oral contraceptives, their purpose of use, or their side effects. When women visited hospitals for COC treatment, many doctors gave them prescriptions without explaining the use of COCs, and the same can be said for pharmacists. Most women were taking COCs based on incorrect information from the Internet without the help of experts [25]. Although a few case reports described single cases of COC-induced 


\title{
Obstetrics \& Gynecology Science
}

\author{
Vol. 64, No. 4, 2021
}

VTE in different Korean hospitals, this study is the first case series to report COC-associated VTE in the country.

The results of this study indicate that 11 of 13 patients with COC-associated VTE did not use COCs for contraceptive purposes. Aside from the 2 patients who could not identify the COCs given to them, 10 of the 11 patients received a $3 \mathrm{rd}$ - or 4th-generation COC. The use of COCs in women diagnosed with obesity will likely increase their risk of VTE, and a BMl greater than $25 \mathrm{~kg} / \mathrm{m}^{2}$ is an independent risk factor for thromboembolism [26-28]. However, this study showed that only 4 patients were obese. The small percentage of patients classified as such could be attributed to the small sample size.

Three patients reported a history of smoking while using COCs. The synergistic effect of smoking and COC use increases the risk of VTE, particularly in those over 35 years of age $[29,30]$. This result emphasizes that women of that age group with a history of smoking should be informed about the higher risk of VTE associated with COC use.

Those who were taking a short-term medication remembered the medication period without a break-in. In comparison, patients who were taking a long-term medication may not recall the exact break-in period and accurately know how long they took and when they stopped taking the COCs. If the 3 patients with missing data were excluded, $50 \%$ of VTE occurred within the first 3 months of use. This result is consistent with previous reports indicating that VTE risk is highest during the same duration $[19,31,32]$, which suggests that long-term COC use does not increase complications.

In this case series, all but 3 patients reported using lowdose EEs (20 or $30 \mu \mathrm{g})$. The fact that most patients were using 3rd- or 4th-generation COCs in this study supported the finding that the risk of COC-associated VTE is $50-80 \%$ higher with COCs containing gestodene, desogestrel, and drospirenone than those containing levonorgestrel [33,34].

For the type of VTE, PE simultaneously occurring with DVT was the most common form of COC-associated VTE in this study, and given the severity of PE associated with COC use, $30 \%$ of patients with PE required thrombolytic therapy as the initial therapeutic approach. Although thrombosis in the cerebral venous system is generally rare, cerebral venous thrombosis was detected in 2 of the 13 patients in this study. Prothrombotic conditions, including antithrombin III, protein $\mathrm{C}$ and $\mathrm{S}$ deficiencies, factor $\mathrm{V}$ Leiden gene mutations, cancer, and oral contraceptive use, are known risk factors for CVT [35]. Two meta-analyses reported that the risk of CVT increased in COC users (relative risk: 15.9, 95\% confidence interval [CI]: 6.98-36.2; odds ratio: 5.59, 95\% Cl: 3.95-7.91) $[36,37]$. None of the patients in this series demonstrated prothrombotic conditions, and COC use was the only risk factor for CVT.

In this study, anticoagulation therapy was continued for more than 3 months in all patients. Three patients consistently took anticoagulants, and none of the patients experienced VTE recurrence. According to a study on patients who experienced an initial untriggered VTE, oral contraceptives could be a provoking factor, with a significantly lower recurrence rate after treatment with anticoagulants for 5 to 7 months compared to women with unproven factors [38]. Anticoagulation medications were stopped after 6 months of treatment because the risk of recurrence in patients with unprovoked VTE with negative D-dimers is low enough to justify stopping therapy, and the rate of VTE recurrence in hormonal users is significantly lower $[39,40]$.

The results indicated that most of the patients in this study were prescribed COCs for non-contraceptive purposes, and they delayed going to the hospital even after the onset of VTE symptoms. These findings emphasize that healthcare professionals who prescribe or dispense COCs to women must inform them of the risk of VTE, including the risk factors, differences in risk depending on the type of progestin present in the product, and pertinent signs and symptoms. Efforts should also be made to inform patients of VTE, even through information campaigns such as brochures. Most importantly, women should remain alert for signs and symptoms of VTE when using COCs.

\section{Conflict of interest}

No potential conflict of interest relevant to this article was reported.

\section{Ethical approval}

The study protocol was reviewed and approved by Soonchunhyang University Hospital's Institutional Review Board and ethics committee (IRB No. 2018-04-011-001). The study was performed in accordance with the principles of the Declaration of Helsinki. 


\section{Obstetrics \& Gynecology Science}

Yong-Su Jang, et al. COC-associated VTE

\section{Patient consent}

Written informed consent and the use of images from patients are not required for the publication.

\section{Funding information}

None.

\section{Acknowledgments}

The authors would like to thank the thrombosis center nurse, Mi-ok Hwang, who helped organize the data.

\section{References}

1. United Nations Department of Economic and Social Affairs. Contraceptive use by method 2019. [Internet] (2019). New York (NY): United Nations Department of Economic and Social Affairs; c2019 [cited 2021 Jan 14]. Available from: https://www.un.org/development/desa/ $\mathrm{pd} /$ sites/www.un.org.development.desa.pd/files/files/ documents/2020/Jan/un_2019_contraceptiveusebymethod_databooklet.pdf.

2. De Leo V, Musacchio MC, Cappelli V, Piomboni P, Morgante G. Hormonal contraceptives: pharmacology tailored to women's health. Hum Reprod Update 2016;22:634-46.

3. Kim JS, Cho S. Clinical use of oral contraceptives. J Korean Med Assoc 2017;60:687-93.

4. Naess IA, Christiansen SC, Romundstad P, Cannegieter SC, Rosendaal FR, Hammerstrøm J. Incidence and mortality of venous thrombosis: a population-based study. J Thromb Haemost 2007;5:692-9.

5. US Food and Drug Administration. FDA Drug Safety Communication: updated information about the risk of blood clots in women taking birth control pills containing drospirenone [Internet]. Silver Spring (MD): US Food and Drug Administration; c2012 [cited 2015 July 17]. Available from: http://www.fda.gov/Drugs/DrugSafety/ ucm299305.htm.

6. Helmerhorst FM, Rosendaal FR. Is an EMA review on hormonal contraception and thrombosis needed? BMJ 2013;346:f1464.

7. Gronich N, Lavi I, Rennert G. Higher risk of venous thrombosis associated with drospirenone-containing oral contraceptives: a population-based cohort study. CMAJ 2011;183:E1319-25.

8. Fruzzetti F, Perini D, Spirito N, Manca R. Oral contraceptive pill and thrombotic risk: epidemiological studies. Minerva Ginecol 2012;64:539-49.

9. Vandenbroucke JP, Rosing J, Bloemenkamp KW, Middeldorp S, Helmerhorst FM, Bouma BN, et al. Oral contraceptives and the risk of venous thrombosis. N Engl J Med 2001;344:1527-35.

10. Bae SH, Kim KH, Whang JY, Lee JM, Kim JM, Ku JM, et al. Treatment by transradial urokinase infusion and percutaneous transhepatic thrombectomy in superior mesenteric veno us thrombosis with intestinal infarction. Korean J Med 2018;93:55-60.

11. Kim JY, Kim YS. Pulmonary embolism and deep vein thrombosis related to oral contraceptive use. Obstet Gynecol Sci 2013;56:273-6.

12. Park MJ, Jeon GH. Pulmonary embolism in a healthy woman using the oral contraceptives containing desogestrel. Obstet Gynecol Sci 2017;60:232-5.

13. Yeo MS, Kwon YS, Choi SH, Kim KH, Byun CG, Koh YT, et al. SMV thrombosis on taking oral contraceptive with protein $C$ and protein $S$ deficiency. Ann Surg Treat Res 2006;71:222-5.

14. Park JH, Yang JH, Yoo DS, Cho KS, Huh PW, Kwon SO, et al. Deep cerebral venous thrombosis: successful treatment by systemic urokinase followed by heparin: case report. J Korean Neurosurg Soc 2001;30:99-104.

15. Cushman M, Kuller LH, Prentice R, Rodabough RJ, Psaty $B M$, Stafford RS, et al. Estrogen plus progestin and risk of venous thrombosis. JAMA 2004;292:1573-80.

16. Lidegaard $\varnothing$, Løkkegaard E, Svendsen AL, Agger C. Hormonal contraception and risk of venous thromboembolism: national follow-up study. BMJ 2009;339:b2890.

17. van Hylckama Vlieg $A$, Helmerhorst FM, Vandenbroucke JP, Doggen CJ, Rosendaal FR. The venous thrombotic risk of oral contraceptives, effects of oestrogen dose and progestogen type: results of the MEGA case-control study. BMJ 2009;339:b2921.

18. Li J, Panucci G, Moeny D, Liu W, Maro JC, Toh S, et al. Association of risk for venous thromboembolism 


\section{Obstetrics \& Gynecology Science}

Vol. 64, No. 4, 2021

with use of low-dose extended- and continuous-cycle combined oral contraceptives: a safety study using the sentinel distributed database. JAMA Intern Med 2018;178:1482-8.

19. Conard J. Biological coagulation findings in thirdgeneration oral contraceptives. Hum Reprod Update 1999;5:672-80.

20. Bladbjerg EM, Skouby SO, Andersen LF, Jespersen J. Effects of different progestin regimens in hormone replacement therapy on blood coagulation factor VII and tissue factor pathway inhibitor. Hum Reprod 2002;17:3235-41.

21. Suzuki A, Sanda N, Miyawaki Y, Fujimori Y, Yamada T, Takagi A, et al. Down-regulation of PROS1 gene expression by 17 beta-estradiol via estrogen receptor alpha (ERalpha)-Sp1 interaction recruiting receptor-interacting protein 140 and the corepressor-HDAC3 complex. J Biol Chem 2010;285:13444-53.

22. Ali HO, Stavik B, Dørum E, Iversen N, Sandset PM, Skretting $G$. Oestrogen induced downregulation of TFPI expression is mediated by ERa. Thromb Res 2014;134:13843.

23. Hughes Q, Watson M, Cole V, Sayer M, Baker R, Staton J. Upregulation of protein $S$ by progestins. J Thromb Haemost 2007;5:2243-9.

24. Kozuka T, Tamura S, Kawamura N, Nakata Y, Hasebe R, Makiyama $A$, et al. Progestin isoforms provide different levels of protein $S$ expression in HepG2 cells. Thromb Res 2016;145:40-5.

25. Lee SH, Lee IY, Kim EA. Experience of taking oral contraceptives in adult women. Korean J Women Health Nurs 2017;23:265-75.

26. Kobayashi T, Sugiura K, Ojima T. Risks of thromboembolism associated with hormone contraceptives in Japanese compared with Western women. J Obstet Gynaecol Res 2017;43:789-97.

27. Sugiura K, Kobayashi T, Ojima T. Risks of thromboembolism associated with hormonal contraceptives related to body mass index and aging in Japanese women. Thromb Res 2016;137:11-6.

28. Parkin L, Sharples K, Hernandez RK, Jick SS. Risk of venous thromboembolism in users of oral contraceptives containing drospirenone or levonorgestrel: nested casecontrol study based on UK General Practice Research Database. BMJ 2011;342:d2139.
29. Lidegaard Ø. Smoking and use of oral contraceptives: impact on thrombotic diseases. Am J Obstet Gynecol 1999;180(6 Pt 2):S357-63.

30. Roy S. Effects of smoking on prostacyclin formation and platelet aggregation in users of oral contraceptives. Am J Obstet Gynecol 1999;180(6 Pt 2):S364-8.

31. Lidegaard $\varnothing$, Edström B, Kreiner $S$. Oral contraceptives and venous thromboembolism: a five-year national casecontrol study. Contraception 2002;65:187-96.

32. Jick H, Jick SS, Gurewich V, Myers MW, Vasilakis C. Risk of idiopathic cardiovascular death and nonfatal venous thromboembolism in women using oral contraceptives with differing progestagen components. Lancet 1995;346:1589-93.

33. de Bastos M, Stegeman BH, Rosendaal FR, Van Hylckama Vlieg A, Helmerhorst FM, Stijnen T, et al. Combined oral contraceptives: venous thrombosis. Cochrane Database Syst Rev 2014;(3):CD010813.

34. Hugon-Rodin J, Gompel A, Plu-Bureau G. Epidemiology of hormonal contraceptives-related venous thromboembolism. Eur J Endocrinol 2014;171:R221-30.

35. Bousser MG, Ferro JM. Cerebral venous thrombosis: an update. Lancet Neurol 2007;6:162-70.

36. Gillum LA, Mamidipudi SK, Johnston SC. Ischemic stroke risk with oral contraceptives: a meta-analysis. JAMA 2000;284:72-8.

37. Dentali F, Crowther M, Ageno W. Thrombophilic abnormalities, oral contraceptives, and risk of cerebral vein thrombosis: a meta-analysis. Blood 2006;107:2766-73.

38. Le Gal G, Kovacs MJ, Carrier M, Do K, Kahn SR, Wells $P S$, et al. Risk of recurrent venous thromboembolism after a first oestrogen-associated episode. Data from the REVERSE cohort study. Thromb Haemost 2010;104:498503.

39. Kearon C, Spencer FA, O'Keeffe D, Parpia S, Schulman $S$, Baglin T, et al. D-dimer Optimal Duration Study Investigators. D-dimer testing to select patients with a first unprovoked venous thromboembolism who can stop anticoagulant therapy: a cohort study. Ann Intern Med 2015;162:27-34.

40. Blanco-Molina Á, Trujillo-Santos J, Pesavento R, Rosa V, Falgá $C$, Tolosa $C$, et al. Outcome after discontinuing anticoagulant therapy in women with venous thromboembolism during hormonal use. Thromb Res 2017;151 Suppl 1:S6-10. 